\title{
Perubahan kualitas hidup, eosinofil mukosa hidung, dan interleukin-5 serum pasien rinitis alergi pasca terapi
}

\author{
Arinda Putri Pitarini*, Nina Irawati*, Niken Lestari Poerbonegoro*, Dewi \\ Wulandari**, Saptawati Badarsono*** \\ *Departemen Telinga Hidung Tenggorok - Bedah Kepala Leher \\ **Departemen Patologi Klinik \\ Fakultas Kedokteran Universitas Indonesia/Rumah Sakit Dr. Cipto Mangunkusumo \\ ***Bagian Gizi Fakultas Kedokteran Universitas Indonesia \\ Jakarta
}

\begin{abstract}
ABSTRAK
Latar belakang: Rinitis alergi adalah suatu penyakit inflamasi pada hidung yang dimediasi oleh imunoglobulin-E, yang terjadi setelah mukosa hidung terpajan alergen. Sel dan mediator inflamasi yang berperan penting adalah eosinofil, histamin, dan sitokin produk Th2. Penyakit ini ditandai dengan gejala rinorea, bersin berulang, hidung tersumbat dan/atau hidung gatal. Selain dari gejala yang mengganggu, rinitis alergi berdampak buruk terhadap kualitas hidup penderita. Tatalaksana komprehensif, meliputi penghindaran alergen, farmakoterapi, imunoterapi dan edukasi, ditujukan untuk menghilangkan gejala dan memperbaiki kualitas hidup pasien. Tujuan: Mengetahui perubahan kualitas hidup, jumlah eosinofil mukosa hidung, dan kadar IL-5 serum pada pasien rinitis alergi setelah mendapat terapi farmaka sesuai panduan. Metode: Penelitian ini merupakan studi pre-eksperimental analitik dengan pengambilan data sebelum dan sesudah pemberian farmakoterapi. Hasil: Sebanyak 31 dari 33 subjek mengalami perubahan kualitas hidup yang bermakna (MID>0,7). Seluruh pasien, 33 subjek memperlihatkan perubahan yang responsif dari jumlah eosinofil mukosa hidung. Sebanyak 30 subjek dinyatakan responsif dan terdapat penurunan kadar IL-5. Tidak ada hubungan yang bermakna antara perubahan kualitas hidup dan kadar IL-5. Kesimpulan: Perubahan kualitas hidup, jumlah eosinofil mukosa hidung, dan kadar IL-5 serum dapat digunakan sebagai penanda objektif keberhasilan terapi rinitis alergi yang dapat dipakai dalam praktik klinis sehari-hari maupun kepentingan riset.
\end{abstract}

Kata kunci: rinitis alergi, kualitas hidup, eosinofil, interleukin-5

\section{ABSTRACT}

Background: Allergic rhinitis defined as an inflammatory disease of the nose mediated by immunoglobulin-E, induced after nasal mucosa exposure to allergen. Important inflammatory cells and mediators are eosinophils, histamine, and Th2-related cytokines. Symptoms include rhinorrhea, repeated sneezing, nasal congestion and/or nasal itching. Aside from its bothersome symptoms, allergic rhinitis decreases patient's quality of life (QOL). Comprehensive management consist of allergen avoidance, medication, immunotherapy, and education, aimed to diminish symptoms and improve the patient's quality of life. Purpose: To evaluate changes in quality of life, nasal mucosal eosinophil count, and level of interleukin-5 in allergic rhinitis after medicamentous treatment. Methods: This was an analytic pre-experimental study with data taken before and after medicamentous treatment. Results: Thirty-one of 33 subjects showed significant changes of QOL (MID>0,7). All samples, 33 subjects, experienced responsive changes in nasal mucosal eosinophil count. Thirty subjects were responsive, which showed decrease of IL-5 level. There was no significant relation between changes of $Q O L$ and changes of IL-5 level. Conclusion: Changes in quality of life, nasal mucosal eosinophil count, and IL-5 level are objective markers of treatment efficacy in Allergic Rhinitis, which can be used in clinical practices and researches.

Keywords: allergic rhinitis, quality of life, eosinophil, interleukin-5, intranasal steroid, antihistamine 
Korespondensi: Niken Lestari Poerbonegoro: Departemen THT-KL Fakultas Kedokteran Universitas Indonesia/RS dr. Cipto Mangunkusumo, Jl. Diponegoro No. 71, Jakarta. Email: niken_lp@yahoo.com

\section{PENDAHULUAN}

Rinitis alergi (RA) merupakan suatu kelainan hidung yang disebabkan oleh proses inflamasi akibat pajanan alergen pada mukosa hidung, yang dimediasi oleh antibodi Imunoglobulin E (IgE) spesifik. Penyakit ini ditandai dengan gejala rinorea, bersin berulang, hidung tersumbat dan/atau hidung gatal. ${ }^{1}$

Prevalensi rinitis alergi cukup bervariasi di setiap belahan dunia. Menurut Stewart et al, ${ }^{2}$ prevalensi RA di seluruh dunia sekitar 10-40\%. Bauchau dan Durham ${ }^{3}$ melaporkan bahwa prevalensi RA pada populasi dewasa di Eropa berdasarkan The European Community Respiratory Health Survey (ECRHS) sebesar $21 \%$ dan pada beberapa negara di Eropa seperti di Belgia sebesar 28,5\%, Perancis $24,5 \%$, Italia $16,9 \%$, Inggris $26 \%$, dan Spanyol 21,5\%. Berdasarkan penelitian Suprihati, ${ }^{4}$ data prevalensi RA di Indonesia yang berasal dari beberapa sentra pendidikan spesialis THT-KL di sekitar Jakarta pada usia di bawah 14 tahun sebesar 10,2\%. Prevalensi RA di Bandung dan sekitarnya pada usia di atas 10 tahun sebesar 5,8\% dan di Semarang, dengan kuesioner ISAAC fase III pada siswa SMP usia 12-15 tahun didapatkan prevalensi gejala RA sebesar $18,6 \% .^{2-5}$

Dalam patofisiologi rinitis alergi, interleukin-5 (IL-5) adalah sitokin yang penting dan sangat spesifik untuk maturasi, perkembangan, aktivasi, dan kelangsungan hidup eosinofil. Sedangkan eosinofil sendiri, memiliki peran penting dalam mengatur mekanisme yang berhubungan dengan alergi dan berperan dalam patogenesis inflamasi alergi. ${ }^{6-9}$ IL-5 berperan pada beberapa fungsi dari eosinofil, di antaranya ialah menurunkan modulasi Mac-1, regulasi dari reseptor untuk IgA dan IgG, menstimulasi sekresi mediator lipid (leukotrien C4 dan PAF), dan menginduksi pelepasan granul. IL-5 juga memengaruhi pertumbuhan dan diferensiasi eosinofil. Hingga saat ini IL-5 sudah lama dikaitkan dengan penyebab alergi termasuk RA dan asma.

Penyakit dikategorikan RA intermiten bila gejala muncul kurang dari 4 hari per minggu atau kurang dari 4 minggu, dan persisten bila gejala timbul lebih dari 4 hari per minggu dan lebih dari 4 minggu. Derajat penyakit dinilai berdasarkan ada atau tidaknya hambatan aktivitas yang memengaruhi kualitas hidup. Derajat dikategorikan ringan apabila tidak terdapat hambatan aktivitas, atau dikategorikan sedang-berat bila terdapat satu atau lebih hambatan. ${ }^{1,10,11}$

Rhinoconjunctivitis Quality of Life Questionnaire (RQLQ), yang dirancang oleh Juniper et al, ${ }^{12}$ menunjukkan bahwa gejala hidung bukanlah satu-satunya masalah yang mengganggu pasien RA. Kuesioner ini lebih akurat menggambarkan keseluruhan aspek kesehatan (fisik, mental, dan kesejahteraan sosial) yang terkait dengan RA. ${ }^{13-15}$

Kuesioner mini kualitas hidup rinokonjungtivitis (Mini-RQLQ) dikembangkan untuk memenuhi kebutuhan versi pendek dan cepat dari $R Q L Q$ dalam rangka uji klinis yang besar dan evaluasi penatalaksanaan, serta memiliki spesifisitas yang baik, uji validitas potong lintang, responsif, dan validitas longitudinal. ${ }^{12}$ Dimensi yang diukur dalam mini RQLQ meliputi activities (3 butir), practical problems (3 butir), nasal symptoms (3 butir), ocular symptoms (2 butir), dan non nasal/ocular symsptoms (3 butir). 


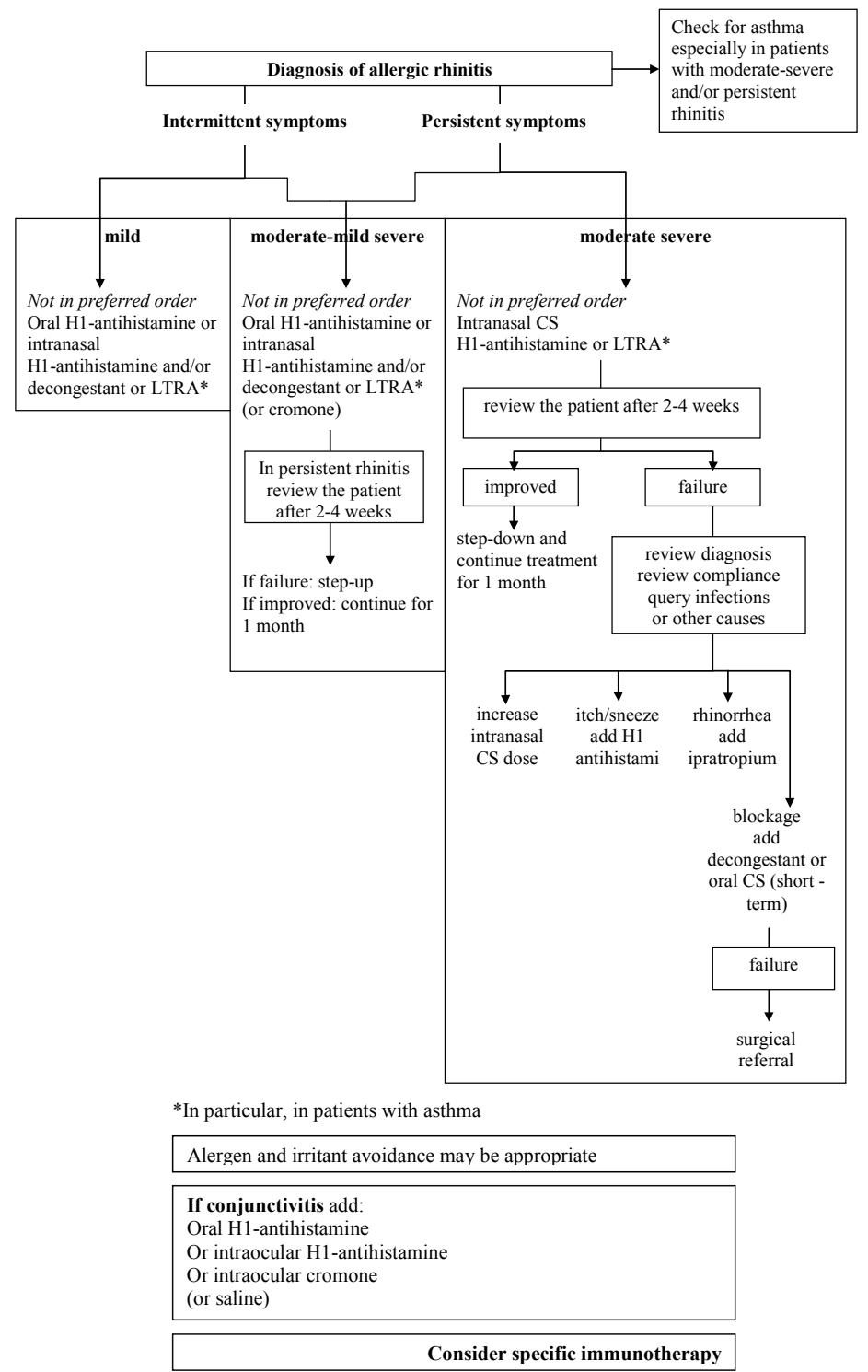

Gambar 1. Algoritma diagnosis dan tatalaksana $\mathrm{RA}^{1}$

Penatalaksanaan RA merupakan kombinasi dari 4 (empat) kategori yaitu 1 . Menghindarikontakdengan alergen penyebab dan kontrol lingkungan. 2. Farmakoterapi. 3. Imunoterapi. 4. Edukasi kepada pasien dan keluarga. Saat ini kortikosteroid intranasal dan antihistamin oral merupakan terapi pilihan karena efektivitasnya yang tinggi namun dengan efek samping yang rendah. Tindakan operasi umumnya dilakukan untuk mengoreksi kelainan anatomi yang dapat memperberat gejala alergi dan menghambat aliran udara hidung atau penghantaran obat ke mukosa hidung. ${ }^{1}$
Di Indonesia, sedikitnya data mengenai kualitas hidup pada pasien RA mendasari penelitian ini untuk mengidentifikasi perubahan kualitas hidup, jumlah eosinofil mukosa hidung, dan kadar IL-5 serum setelah terapi, dengan melakukan pemeriksaan secara kualitatif menggunakan kuesioner mini RQLQ dan secara kuantitatif menggunakan hitung jumlah eosinofil dan kadar IL-5 serum, sehingga diperoleh data yang lebih lengkap.

\section{METODE}

Penelitian initelah mendapatpersetujuan Panitia Tetap Etik Penelitian Kedokteran 
FKUI/RSCM. Penelitian ini menggunakan metode pre-eksperimental yang bersifat analitik, yang dilakukan di Departemen THT-FKUI/RSCM dan di Departemen Patologi Klinik FKUI/RSCM pada bulan Maret-Desember 2014. Pengambilan sampel dilakukan secara consecutive sampling.

Subjek penelitian adalah seluruh pasien RA persisten kategori sedang-berat, berusia 18-60 tahun yang datang berobat ke bagian THT FKUI/RSCM, dan bersedia mengisi surat persetujuan(informed consent). Kriteria penolakan adalah pasien yang disertai rinosinusitis akut, rinosinusitis kronis, polip nasi, massa kavum nasi, dan septum deviasi dengan contact point. Pasien yang sedang dalam pemakaian steroid intranasal dan antihistamin tidak diikut-sertakan. Subjek penelitian dikeluarkan dari penelitian apabila berhenti menggunakan obat yang diberikan peneliti sebelum masa penilaian selesai.

Alur penelitian diawali dengan subjek penelitian mengisi kuesioner Mini $R Q L Q$ disertai penjelasan dari peneliti. Instrumen tersebut memiliki 14 pertanyaan dalam lima domain (keterbatasan aktivitas, masalahmasalah praktis, gejala hidung, gejala mata, dan gejala non-hidung/mata). Subjek penelitian kemudian menjalani pemeriksaan fisik THT, dilanjutkan dengan menggunakan alat nasoendoskop $0^{\circ}$ untuk menyingkirkan adanya kelainan anatomi atau penyakit lain. Kerokan mukosa hidung dilakukan menggunakan rhinoprobe ${ }^{\circledR}$ pada konka inferior, selanjutnya dioleskan di atas kaca objek dan dicelupkan ke dalam alkohol 70\% untuk fiksasi dan diperiksa hitung eosinofil. Pengambilan darah subjek penelitian untuk pemeriksaan kadar IL-5. Setelah menjalani pemeriksaan, subjek penelitian diberikan terapi steroid topikal hidung (fluticasone furoate $110 \mu \mathrm{g} / \mathrm{hari}$ ) dan antihistamin (cetirizine $10 \mathrm{mg} / \mathrm{hari}$ ) selama 2 minggu. Pada akhir terapi, subjek penelitian mengisi kembali kuesioner Mini RQLQ, dan menjalani lagi pemeriksaan kerokan mukosa hidung dan pengambilan darah untuk kadar IL-5 serum. Cara menghitung skor Mini RQLQ yaitu dengan menghitung rerata skor tiap domain, kemudian rerata skor kelima domain tersebut, dijumlahkan, dan dibagi lima. Selisih skor sebelum dan setelah terapi dihitung. Apabila nilai selisih lebih besar atau sama dengan nilai minimal important difference (MID), maka kualitas hidup dianggap mengalami perbaikan (Nilai MID untuk Mini RQLQ yaitu 0,7). ${ }^{12,16,17}$ Hitung eosinofil mukosa hidung berupa: 0 (tidak ditemukan eosinofil); $1 / 2+$ (0,1-1,0 sel/10 lpb); $1+(1,1-5,0 \mathrm{sel} / 10 \mathrm{lpb})$; $2+(6,0-15,00 \mathrm{sel} / 10 \mathrm{lpb}) ; 3+(16,0-20,0 \mathrm{sel} / 10$ lpb) dan $4+(>20,0 \mathrm{sel} / 10 \mathrm{lpb}) .{ }^{18}$ Pasca terapi dinyatakan responsif bila jumlah eosinofil setelah terapi sama dengan nol dan dinyatakan tidak responsif bila jumlah eosinofil setelah terapi lebih besar dari nol. Kadar interleukin-5 serum ditentukan dari hasil pemeriksaan darah menggunakan ELISA.

\section{HASIL}

Penelitian ini melibatkan 33 subjek RA persisten kategori sedang-berat dengan jumlah subjek penelitian laki-laki sebanyak 14 orang dan perempuan sebanyak 19 orang. Pada penelitian ini, rerata usia subjek yaitu 32,55 tahun. Mayoritas subjek memiliki pekerjaan pada lingkungan tertutup (indoor) yaitu sebanyak 32 subjek dan 1 subjek memiliki pekerjaan pada lingkungan terbuka (outdoor).

Perubahan kualitas hidup pasien RA persisten kategori sedang-berat sebelum dan dua minggu setelah terapi dievaluasi menggunakan nilai minimal important difference (MID). Apabila nilai $M I D>0,7$ maka subjek mengalami perubahan bermakna pada kualitas hidupnya dan bila nilai $M I D<0,7$ maka perubahan kualitas hidup subjek dianggap tidak bermakna. Sebagian besar subjek penelitian mengalami perubahan kualitas hidup, yaitu sebanyak 31 subjek mengalami perubahan 
kualitas hidup secara bermakna dan 2 subjek lainnya mengalami perubahan kualitas hidup yang tidak bermakna.

Perubahan hitung eosinofil mukosa hidung dikatakan responsif bila setelah terapi selama 2 minggu tidak ditemukan eosinofil pada pemeriksaan kerokan mukosa hidung dan perubahan dikatakan tidak responsif bila masih ditemukan eosinofil pada pemeriksaan kerokan mukosa hidung dari setiap subjek penelitian. Pada penelitian ini, didapatkan perubahan yang responsif dari jumlah eosinofil mukosa hidung terhadap seluruh subjek penelitian yang berjumlah 33 .

Perubahan kadar IL-5 dikatakan responsif bila setelah terapi 2 minggu didapatkan kadar IL-5 lebih rendah dibandingkan kadar sebelum terapi dan kadar IL-5 dikatakan tidak responsif bila setelah terapi 2 minggu didapatkan kadar IL-5 menjadi lebih tinggi dibandingkan kadar sebelum terapi. Pada penelitian ini, dari 33 subjek penelitian, didapatkan sebanyak 30 subjek yang responsif terhadap terapi yang dilakukan selama 2 minggu dan yang tidak responsif terhadap terapi sebanyak 3 subjek.

Tabel 1. Perubahan kualitas hidup pasien, jumlah eosinofil mukosa hidung dan kadar IL 5 pasien RA persisten sedang berat sebelum dan setelah terapi

\begin{tabular}{lc}
\hline Variabel & n \\
\hline Perubahan skor Mini RQLQ & 31 \\
Bermakna & 2 \\
Tidak bermakna & \\
Perubahan jumlah eosinofil & 33 \\
Responsif & 0 \\
Tidak responsif & \\
Perubahan kadar IL 5 & 30 \\
Responsif & 3 \\
Tidak responsif & \\
\hline
\end{tabular}

Tabel 2. Hubungan perubahan kualitas hidup pasien RA persisten sedang berat dan perubahan kadar IL-5 serum (*uji chi square)

\begin{tabular}{llrrrr}
\hline \multicolumn{7}{c}{ Kualitas hidup } \\
\hline \\
\hline IL 5 & & Bermakna & Tidak bermakna & Total & \multicolumn{1}{c}{ * $^{*}$} \\
& Responsif & 28 & 2 & 30 & \\
Total & Non responsif & 3 & 0 & 3 & 0,645 \\
\hline
\end{tabular}

Tabel 2 menunjukkan hasil analisis bivariat untuk mencari hubungan kualitas hidup pasien RA persisten sedang-berat dengan kadar IL-5 serum. Dari 31 subjek yang mengalami perubahan kualitas hidup yang bermakna, sebanyak 28 subjek memperlihatkan perubahan kadar IL-5 serum yang responsif dan 3 subjek dengan kadar IL-5 non responsif.
Dua subjek dengan perubahan kualitas hidup yg tidak bermakna memperlihatkan perubahan IL-5 serum yang responsif. Secara statistik tidak didapatkan hubungan yang bermakna antara perubahan kualitas hidup dan perubahan kadar IL-5 (uji chisquare, $\mathrm{p}>0,05$ ). 


\section{DISKUSI}

Pada penelitian ini didapatkan rerata usia seluruh subjek penelitian adalah 32,55 tahun. Subjek penelitian terdiri dari 14 orang laki-laki dan 19 orang perempuan. Berdasarkan penelitian dari Valero et al, ${ }^{19}$ mengenai kualitas hidup pada pasien RA menggunakan kuesioner Mini RQLQ, menemukan bahwa sekitar $62 \%$ dari 400 subjek penelitiannya adalah perempuan. Bachert $^{20}$ dalam penelitiannya mengenai prevalensi RA pada populasi di Belgia yang sampelnya diambil secara repesentatif, juga mendapatkan sebanyak 52,2\% dari 4959 subjek penelitiannya adalah perempuan. Rerata usia pasien dengan RA persisten sedang-berat pada penelitian Valero et $\mathrm{al}^{19}$ adalah 32,3 tahun. Gejala rinitis akan menjadi ringan seiring dengan bertambahnya usia. ${ }^{1}$ Nathan et $\mathrm{al}^{21}$ dalam penelitiannya juga mengatakan bahwa prevalensi RAdidapatkan tertinggi pada usia 18 sampai 49 tahun dan menurun setelah usia 50 tahun. Hal ini dapat menjadi salah satu penyebab RA persisten sedang-berat dalam penelitian ini ditemukan pada usia muda. Pekerjaan subjek pada penelitian ini dikategorikan menjadi dua yaitu indoor dan outdoor. Subjek penelitian hampir semuanya memiliki pekerjaan pada lingkungan di dalam ruangan (indoor), yaitu dari 33 subjek penelitian, sebanyak 32 bekerja pada lingkungan indoor dan 1 subjek penelitian bekerja pada lingkungan di luar ruangan (outdoor). Sebagian besar dari populasi penduduk di negara barat menghabiskan waktunya di dalam ruangan. ${ }^{1}$

Penelitian ini melihat perubahan kualitas hidup dengan menggunakan kuesioner Mini $R Q L Q$, yang dinilai dari skor $M I D$, pada pasien RA persisten sedang-berat sebelum dan 2 minggu setelah diobati. Dari 33 subjek penelitian, sebanyak 31 subjek mengalami perubahan yang bermakna dan 2 subjek lainnya mengalami perubahan kualitas hidup yang tidak bermakna. Hasil penelitian ini sesuai dengan penelitian yang dilakukan oleh Juniper et al ${ }^{12}$ yang menyebutkan bahwa kuesioner Mini $R Q L Q$ memiliki reliabilitas yang baik untuk menilai kualitas hidup pada 100 pasien dengan RA, yang dilihat dari nilai $M I D>0,7$, stabil pada 83 pasien selama kunjungan 5 minggu berturut-turut. Valero et al $^{19}$ pada penelitiannya menggunakan kuesioner Mini RQLQ, menyebutkan bahwa dari 400 pasien RA yang diteliti, sebanyak $59 \%$ pasien juga memiliki MID $>0,7$. Penelitian ini juga memperlihatkan bahwa kuesioner Mini RQLQ adalah kuesioner yang baik untuk menilai kualitas hidup penderita RA khususnya RA persisten sedang-berat.

Dua subjek yang mengalami perubahan tidak bermakna pada saat kontrol ternyata diketahui memakai obat tidak teratur dan melaksanakan kontol lingkungan sesuai arahan. Hal ini menyebabkan keluhan masih dirasakan.

Rinitis alergi secara nyata memengaruhi kualitas hidup, kinerja, belajar dan produktivitas pasien. Derajat penyakit ternyata memiliki efek yang lebih relevan pada kualitas hidup pasien dengan RA dibandingkan durasi gejala klinis, yang berdampak terhadap kualitas tidur dan kinerja. ${ }^{23}$

Hasil dari banyak penelitian yang mengkombinasikan steroid intranasal dengan antihistamin oral menunjukkan keuntungan yang tidak signifikan dibandingkan dengan terapi tunggal dengan steroid intranasal topikal pada perbaikan total nasal symptom score (TNSS) dan total symptom score (TSS). Sebagai contoh penelitian multisenter, secara acak, doubleblind, kontrol plasebo terhadap 702 pasien selama 15 hari, dengan menambahkan loratadine ke semprot hidung mometasone furoate memberikan keuntungan yang tidak signifikan dibandingkan terapi tunggal semprot hidung mometasone furoate untuk gejala RA musiman. Bagaimanapun, pada penelitian 95 pasien dengan RA, semprot hidung mometasone furoate ditambah 
desloratadine atau montelukast menunjukkan perbaikan yang signifikan pada skor TNSS dibandingkan terapi tunggal semprot hidung mometasone furoate. ${ }^{24}$

Seluruh subjek pada penelitian ini mengalami perubahan jumlah eosinofil yang responsif. Dari literatur yang ada, belum terdapat penelitian yang menilai perubahan jumlah eosinofil mukosa hidung sebelum dan dua minggu setelah terapi dengan metode kerokan menggunakan rhinoprobe ${ }^{\circledR}$ pada pasien RA persisten sedang-berat. Beberapa literatur yang ada, di antaranya penelitian yang dilakukan oleh Ahmadiashfar et $\mathrm{al}^{8}$ menyebutkan pada 50 pasien RA, terdapat 37 pasien yang hasil usap hidungnya diidentifikasi positif terdapat eosinofil. Penelitian tersebut mengatakan bahwa eosinofil adalah sel efektor utama yang terlibat dalam inflamasi akibat alergi.

Satu penelitian menemukan bahwa masa hidup eosinofil dipengaruhi kondisi media seperti epitel mukosa hidung. Semprot hidung mometasone furoate dikombinasikan dengan desloratadine menghambat masa hidup eosinofil lebih signifikan dibanding dengan terapi tunggal $(p<0,01) .{ }^{24}$

Penelitian lain oleh Liu et $\mathrm{al}^{25}$ mengemukakan bahwa hitung eosinofil pada kelompok pasien dengan RA persisten berat meningkat secara signifikan bila dibandingkan dengan kelompok kontrol. D'Costa et $\mathrm{a}^{18}$ mengatakan pada penelitiannya bahwa jumlah eosinofil dari kerokan mukosa hidung lebih tinggi pada kelompok anak dengan RA persisten sedangberat bila dibandingkan dengan kelompok kontrol. Pada penelitian yang dilakukan oleh Mullol et $\mathrm{al}^{26}$ yang menggunakan model in vitro berupa spesimen mukosa hidung pasien yang menjalani koreksi septum, hipertrofi konka atau keduanya, menyebutkan bahwa efek anti inflamasi dari fluticasone furoate dapat menurunkan sekresi sitokin pro inflamasi dari sel epitel mukosa hidung manusia dan menurunkan kelangsungan hidup eosinofil. Hal tersebut sesuai dengan hasil penelitian ini yang seluruh subjek penelitiannya mengalami perubahan jumlah eosinofil yang responsif terhadap terapi RA selama 2 minggu.

WHO-ARIA merekomendasi antihistamin terbaru yang bersifat non-sedatif dan memiliki efek anti inflamasi untuk tata laksana RA. ${ }^{1}$ Efek Cetirizine terhadap eosinofil pasien RA diteliti secara in vitro oleh Sedgwick dan Busse. ${ }^{27}$ Penelitian tersebut menunjukkan bahwa konsentrasi cetirizine $100 \mathrm{~mol} / \mathrm{l}$ secara signifikan menghambat masa hidup eosinofil pada 48 jam $(p=0,0201)$ dan 72 jam $(p=0,0025)$. Efek ini tidak terjadi pada konsentrasi cetirizine $<100 \mathrm{~mol} / \mathrm{l}$, yang lebih besar dari kadar di jaringan yang dicapai dengan dosis klinis.

Sebanyak 30 dari 33 subjek pada penelitian ini didapati kadar IL-5 responsif terhadap terapi yang diberikan selama 2 minggu dan 3 subjek penelitian mengalami perubahan yang tidak responsif. Penelitian oleh Liu et al ${ }^{25}$ mengemukakan bahwa kadar IL-5 serum pada kelompok pasien dengan RA persisten berat meningkat secara signifikan bila dibandingkan dengan kelompok kontrol. Menurut penelitian yang dilakukan oleh Mostafa et al, ${ }^{28}$ fluticasone furoate efektif untuk menurunkan jumlah eosinofil dan kadar IL-5 yang diperiksa dari biopsi mukosa konka inferior pasien RA, sebelum dan setelah pengobatan selama 1, 6, dan 12 bulan. IL-5 meningkat pada bilasan hidung pasien dengan alergi terhadap tungau debu rumah, dan jumlah dari sitokin ini menurun setelah pemberian glukokortikosteroid intranasal. ${ }^{1}$ Sebanyak 3 subjek penelitian yang mengalami perubahan tidak responsif setelah 2 minggu terapi dapat diakibatkan oleh berbagai faktor seperti memakai obat tidak teratur, tidak melaksanakan kontol lingkungan sesuai arahan, serta waktu follow up dari penelitian ini yang hanya 2 minggu. 
Penelitian ini menemukan tidak ada hubungan bermakna antara kualitas hidup pasien RA persisten sedang-berat dengan kadar IL-5 $(p=0,645)$. Penelitian yang dilakukan oleh Segundo et $\mathrm{al}^{29}$ melaporkan bahwa didapatkan perbaikan keluhan pada seluruh subjek penelitian, yaitu sebanyak 24 subjek RA, yang dibagi ke dalam 3 kelompok pengobatan (montelukast 5 mg, oral, satu hari sekali; mometasone furoat intranasal, $50 \mu \mathrm{g}$, satu hari sekali; atau desloratadine, $5 \mathrm{mg}$, satu hari sekali). Dilakukan pemeriksaan IL-5 dari bilasan hidung dan didapatkan penurunan kadar IL-5 pada kelompok yang diberikan mometasone dibandingkan sebelum terapi, namun tidak didapatkan perubahan kadar IL-5 pada kelompok montelukast atau desloratadine sebelum dan setelah terapi. Pada penelitian yang dilakukan oleh Segundo et al, ${ }^{29}$ seluruh subjek mengalami perbaikan keluhan namun terdapat perbedaan dari perubahan kadar IL-5 ketiga kelompok dan tidak dilakukan penilaian secara statistik mengenai hubungan perubahan kualitas hidup berdasarkan keluhan dengan kadar IL-5.

Penggunaan mometasone furoat dan fluticasone propionat selama 12 bulan menunjukkan tidak ada bukti atrofi atau metaplasia.

Keterbatasan penelitian ini antara lain alat untuk melakukan kerokan mukosa hidung yaitu rhinoprobe® sulit didapatkan karena hanya bisa dibeli langsung di Amerika dan digunakan untuk kebutuhan penelitian. Diharapkan dilakukan penelitian dengan waktu follow up yang lebih panjang agar didapatkan perubahan jumlah eosinofil mukosa hidung dan kadar IL-5 yang lebih representatif.

Sebagai kesimpulan, perubahan kualitas hidup penderita rinitis alergi setelah terapi, dengan menggunakan kuesioner Mini RQLQ, dapat dipakai sebagai penanda objektif keberhasilan farmakoterapi yang dapat dipakai dalam praktik klinis sehari- hari. Selain itu, perubahan hitung eosinofil mukosa hidung dan kadar IL-5 serum juga merupakan penanda objektif keberhasilan terapi yang terutama digunakan untuk kepentingan riset.

\section{DAFTAR PUSTAKA}

1. Bousquet J, Khaltaev N, Cruz A, Denburg J, Fokkens W, Togias A, et al. Allergic Rhinitis and it's impact on asthma (ARIA) 2008 update (in collaboration with the World Health Organization, GA(2)LEN and AllerGen). Allergy. 2008; 8-160 p.

2. Stewart M, Ferguson B, Fromer L. Epidemiology and burden of nasal congestion. International Journal of General Medicine. 2010;3:37-45.

3. Bachau V, Durham SR. Prevalence and rate of diagnosis of allergic rhinitis in Europe. The European respiratory journal: official journal of the European Society for Clinical Respiratory Physiology. 2004;24(5):758-64.

4. Suprihati. Manajemen Pilek Alergi Pencegahan dan Peningkatan Kualitas Hidup. Semarang: Universitas Diponegoro; 2011.

5. Greiner AN, Hellings PW, Rotiroti G, Scadding GK. Allergic rhinitis. Lancet. 2011; 378(9809):2112-22

6. Adamko DJ, Wu Y, Ajamian F, Ilarraza R, Moqbel R, Gleich GJ. The effect of cationic charge on release of eosinophil mediators. The Journal of allergy and clinical immunology. 2008;122(2):383-90.

7. Egan R, Umland S, Cuss F, Chapman W. Biology of interkeukin-5 and its relevance to allergic disease. Allergy. 1996;51:71-81.

8. Ahmadiafshar A, Taghiloo D, Esmailzadeh A, Falakaflaki B. Nasal eosinophilia as a marker for allergic rhinitis: A controlled study of 50 patients. Ear, Nose \& Throat Journal. 2012;91(3):122-4 
9. Wikipedia. Allergic rhinitis. [cited 2013 9]; Available from: http://en.wikipedia.org/wiki/ Allergic_rhinitis.

10. Tripathi A, Patterson R. Impact of allergic rhinitis treatment on quality of life. Pharmacoeconomics. 2001;19(9):891-9.

11. Skoner DP. Allergic rhinitis: definition, epidemiology, patophysiology, detection, and diagnosis. The Journal of allergy and clinical immunology. 2001;108(1):S2-8.

12. Juniper EF, Thompson AK, Ferrie PJ, Roberts JN. Development and validation of the Mini Rhinoconjunctivitis Quality of Life Questionnaire. Clinical allergy. 2000;30(1):132-40.

13. Djauzi S, Karjadi T. Perbaikan kualitas hidup pada karyawan penderita alergi. Cermin Dunia Kedokteran. 2004;142:15-8.

14. Hilger P. Hidung: Anatomi dan fisiologi terapan. In: Adams G, Boeis L, Higler P, editors. Buku ajar penyakit THT. Jakarta: Penerbit buku kedokteran EGC, 1997. p.17389.

15. Krouse J. Allergic and Nonallergic Rhinitis. In: BJ BB, Johnson J, Newlands S, editors. Head \& Neck Surgery Otolaryngology. Fourth ed. Philadelphia 2006. p. 351-63.

16. Juniper EF, Guyatt GH, Griffith LE, Ferrie PJ. Interpretation of rhinoconjunctivitis quality of life questionnaire data. The Journal of allergy and clinical immunology. 1996;98(4):843-5.

17. Juniper EF, Thompson AK, Ferrie PJ, Roberts $\mathrm{JN}$. Validation of the standardized version of the Rhinoconjunctivitis Quality of Life Questionnaire. The Journal of allergy and clinical immunology. 1999;104(2):364-9.

18. D'costa G, Candes A, Shedge R. Quantitative cytology of nasal secretion and scrapings in children with perennial allergic rhinitis. Bombay Hospital Journal. 2009;51(4):422-6.
19. Valero A, Alonso J, Antepara I, Baró E, Colás C, Cuvillo Ad, et al. Health-related quality of life in allergic rhinitis: comparing the short form ESPRINT-15 and Mini RQLQ questionnaires. Allergy. 2007;62(12):1372-8.

20. Bachert C, Cauwenberge P, Olbrecht J, Schoor J. Prevalence, classification and perception of allergic and nonallergic rhinitis in Belgium. Allergy. 2006;61(6):693-8.

21. Nathan RA, Meltzer EO, Seiner JC, Storms W. Prevalence of allergic rhinitis in the United States. The Journal of Allergy and Clinical Immunology. 1997;99(6):S808-S814.

22. Nathan R. The pathophysiology, clinical impact, and management of nasal congestion in allergic Rhinitis. Clinical Therapeutics. 2008;30(4):573-86.

23. Mabry R. Allergic Rhinosinusitis. In: Bailey B, editor. Head and Neck SurgeryOtolaryngology. $3^{\text {rd }}$ ed. Philadelphia: Lippincott-Raven; 2001. p. 281-91.

24. Meltzer E. Pharmacotherapeutic strategies for allergic rhinitis: Matching treatment to symptoms, disease progression, and associated conditions. Allergy and asthma proceedings: the official journal of regional and state allergy societies. 2013;34(4):30111.

25. Liu F, Zhang J, Liu Y, Zhang N, Holtappels $\mathrm{G}$, Lin $\mathrm{P}$, et al. Inflammatory profiles in nasal mucosa of patients with persistent vs intermittent allergic rhinitis. Allergy. 2010;65(9):1149-57.

26. Mullol J, Pujols L, Alobid I, Pérez-Gonzalez M, Fuentes M,de Borje Callejas F, et al. Fluticasone furoate inhibits cytokine secretion from nasal epithelial cells and reduces eosinophil survival in an in vitro model of eosinophilic inflammation. International archives of allergy and immunol. 2014;163(3):225-33. 
27. Sedgwick JB, Busse WW. Inhibitory effect of cetirizine on cytokine-enhanced in vitro eosinophil survival. Annals of allergy. 1997;78(6):581-5.

28. Mostafa HS, Fawzy TO, Ayad E, Soliman AA. Effect of a prolonged topical glucocorticosteroid on interleukin-5 production and eosinophilic recruitment in the nasal submucosal compartment. The Egyptian Journal of Otolaryngology. 2013;29:151-155.
29. Segundo GR, Gomes FA, Fernandes KP, Alves R, Silva DA, Taketomi EA. Local cytokines and clinical symptoms in children with allergic rhinitis after different treatments. Biologics. 2009;3:469-74. 